\title{
First isolation of a rhabdovirus from perch Perca fluviatilis in Switzerland
}

\author{
Thomas Wahli ${ }^{1, *}$, Laure Bellec ${ }^{2}$, Beat von Siebenthal ${ }^{1}$, Joëlle Cabon ${ }^{2}$, \\ Heike Schmidt-Posthaus ${ }^{1}$, Thierry Morin ${ }^{2}$
}

\author{
${ }^{1}$ Centre for Fish and Wildlife Health, Department of Infectious Diseases and Pathobiology, University of Bern, \\ Laenggassstrasse 122, 3012 Bern, Switzerland
}

${ }^{2}$ French Agency for Food, Environmental and Occupational Health \& Safety, Ploufragan-Plouzané Laboratory, Viral Disease of Fish Unit, European University of Brittany, Technopôle Brest Iroise, CS 10070, 29280 Plouzané, France

\begin{abstract}
Perca fluviatilis is a fish species of increasing interest to the Swiss fish farming industry. In recent years, recirculation systems have been specifically set up to increase production. In one of these farms, abnormal spiral swimming associated with elevated mortalities occurred in repeated batches of imported perch shortly after stocking on several occasions. No bacterial or parasitic etiology was detected, but a virus grown in bluegill fry (BF-2) cells was identified as perch rhabdovirus. Subsequent investigations of other samples suggested a viral tropism for the central nervous system (CNS). Phylogenetic analysis of the partial N and entire G gene sequences positioned this isolate in genogroup $\mathrm{C}$ of the species Perch rhabdovirus, with high nucleotide and amino acid (aa) sequence identities with the DK5533 strain isolated in Denmark in 1989. Comparative studies using other closely related isolates allowed the distinction of 2 serological patterns among perch rhabdoviruses and the identification of a proline substitution by a serine in position 147 of the glycoprotein potentially involved in antigenic differentiation. Even if perch imported onto the farm tested negative by virus isolation prior to transport, they may have been the origin of this outbreak since CNS tissue was not included in the samples that were analyzed. Another possibility might be a sub-clinical infection with a viral load in resident fish too low to be detected. This study reports the first isolation of a perch rhabdovirus in Switzerland, and emphasizes the necessity of optimizing diagnostic tools that facilitate better control of the risks associated with fish translocation.
\end{abstract}

KEY WORDS: Perca fluviatilis · Perch rhabdovirus · IFAT $\cdot$ Phylogenetic analysis $\cdot$ Serogroup Resale or republication not permitted without written consent of the publisher

\section{INTRODUCTION}

Rhabdoviruses infect a wide range of hosts, including vertebrates, invertebrates and plants (Healy et al. 2013). They are among the most devastating viruses for aquaculture and under certain circumstances can cause a significant ecological impact on wild fish populations (Al-Hussinee et al. 2011, Faisal et al. 2012). For salmonids, the most important representatives are the 2 novirhabdoviruses, viral haemorrhagic septicaemia virus (VHSV) and infectious hematopoietic necrosis virus (IHNV), which have been reported from a wide range of host species (OIE 2014) and are regulated in the European Union (Anonymous 2006) as well as in Switzerland (Anonymous 1995). The number of incidents associated with these viruses has been greatly reduced in Europe in recent years due to significant health monitoring efforts and improved control of fish trade (Anonymous 2006). The spring viraemia of carp virus (SVCV), member of the genus Spirivirus, is another rhabdovirus of major importance for the cyprinid and 
ictalurid farming sectors (Ahne et al. 2002, Hoffmann et al. 2002). While VHSV, IHNV and SVCV have been extensively investigated, other less-studied rhabdoviruses require further research as they are now impacting on new species being considered for aquaculture (Betts et al. 2003, Way et al. 2003, Stone et al. 2013). In Switzerland, one such fish species is the European perch Perca fluviatilis. With the full life cycle of this fish species now established in recirculation systems, perch has become a candidate species for farming due to high market prices and good flesh quality. However, as a consequence of culture intensification and insufficient knowledge of potential pathogens, infectious diseases resulting in high economic losses might hamper the development of this aquaculture sector. Perch rhabdovirus is considered a pathogen that could cause major losses during culture of European perch (Dorson et al. 1984, Betts et al. 2003). This virus was first isolated in cell culture in France in 1980 from wild perch captured and acclimated to laboratory conditions (Dorson et al. 1984). Affected fish showed loss of equilibrium and impaired swimming behavior associated with 30\% cumulative mortality. Similar epizootics were reported later in other European countries, e.g. Denmark, Ireland, Sweden, Germany and Norway (Jørgensen et al. 1993, Dannevig et al. 2001) and occasionally in wild populations that are often a source of eggs and broodstock for farms (Pozet \& Morand 2005). Based on several phylogenetic studies, the International Committee of Taxonomy of Viruses (ICTV) has recently positioned the perch rhabdoviruses in the new genus, Perhabdovirus, together with 2 other species: Anguillid rhabdovirus and Sea trout rhabdovirus (STRV) (Talbi et al. 2011, Galinier et al. 2012, ICTV 2013, Gadd et al. 2013, Stone et al. 2013).

In 2013, elevated mortalities in a commercial perch farm located in Switzerland were recorded on at least 3 different occasions 2 to 3 wk after stocking imported fish. During the last outbreak, affected fish were sent to the Centre for Fish and Wildlife Health (FIWI) for diagnosis. Here, we describe the isolation and partial characterization of a virus associated with these mortality events.

\section{MATERIALS AND METHODS}

\section{Fish husbandry and sampling}

Fish were kept in a commercial fish farm in a semirecirculation system in PVC round tanks supplied with geothermal water at a temperature of 19 to $20^{\circ} \mathrm{C}$. Initially, 8 fish with a total length between 6.1 and $7.1 \mathrm{~cm}$ showing abnormal swimming behavior were submitted for diagnosis (Submission 1). A second sample set taken 8 d later consisted of 3 groups: (1) fish showing abnormal swimming from the same tank as Submission 1 (Submission 2), (2) fish from the same tank but without signs of abnormal swimming behavior (Submission 3), and (3) fish from another tank with no abnormal swimming behavior (Submission 4). The perch of the 3 latter groups measured between 6 and $20 \mathrm{~cm}$. Each group consisted of 5 to 7 fish. All tanks operated on the same recirculation system.

\section{Post mortem examination}

Upon arrival at the FIWI, fish were euthanized with an overdose of MS222 (tricaine methanesulfonate, Argent Laboratories). Necropsies as well as parasitological, bacteriological and virological investigations were performed on fish from Submission 1 (see below). Tissue samples were fixed for histology in $10 \%$ formalin. Fish from Submissions 2 to 4 were processed for virus isolation only. Parasitological analyses consisted of the examination of fresh mounts from the skin, gills and intestinal tract. For bacteriology, sterile loops were used to collect samples from the liver, spleen and kidney. These samples were used to inoculate commercial sheep blood agar (Biomerieux). For virology of Submission 1, tissues (heart, spleen, caeca pylorica, kidney and brain) were pooled; pools from Submissions 2 to 4 consisted of the same tissues except for the brain, which was analyzed separately. Approximately $0.5 \mathrm{~g}$ of tissue was placed in $4.5 \mathrm{ml}$ of antibiotic solution (106 IU penicillin $\mathrm{G}, 10 \mathrm{ml}$ amphotericin $\mathrm{B}, 1 \mathrm{~g}$ streptomycin $\mathrm{l}^{-1}$ double distilled water). The pieces were then homogenized with a Stomacher 80 (Seward) and the homogenate was stored at $4^{\circ} \mathrm{C}$ overnight.

\section{Virus isolation}

The samples were centrifuged $(2000 \times g)$ for $20 \mathrm{~min}$ at $4^{\circ} \mathrm{C}$. Then $100 \mu \mathrm{l}$ of the supernatant as well as $100 \mu \mathrm{l}$ of a 1:10 dilution in phosphate-buffered saline (PBS; pH 7.2) were inoculated onto 24-well plate cultures of both bluegill fry (BF-2) and epithelioma papulosum cyprini (EPC) cell lines. The cell cultures were then incubated at $15^{\circ} \mathrm{C}$ and checked at least every other day for the development of cytopathic 
effect (CPE). A blind passage was done after $7 \mathrm{~d}$; $100 \mu \mathrm{l}$ of supernatant from each well was transferred into a fresh cell culture well and incubated for another $7 \mathrm{~d}$ period. If no CPE was observed, the sample was considered negative. For cultures that developed $\mathrm{CPE}$, viruses were identified by indirect fluorescent antibody technique (IFAT).

\section{Virus identification by IFAT}

The IFAT used for the initial identification of viruses grown on cell cultures was undertaken according to Commission Decision of the European Community (Anonymous 2001) using the BIOFLUO kit (Bio-X) following the manufacturer's recommendation.

Briefly, for cultures derived from each submission the supernatant was removed from each well showing CPE the cells were scraped off and pooled together and using a pipette. One drop of the pooled cells was placed into each of 6 wells of a defatted glass slide (standard $25 \times 75 \mathrm{~mm}$ glass slide with a protecting layer except for 12 wells of

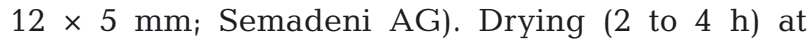
room temperature (RT) was followed by fixation with $100 \%$ isopropanol (40 to $60 \mathrm{~min}$ ) and drying (15 min, RT). The slides were then stored at $-20^{\circ} \mathrm{C}$ until analysis. Cells infected with known viruses were treated in the same manner for use as positive controls. After thawing, slides with fixed cells were washed (10 $\mathrm{min}, \mathrm{PBS})$ and dried (15 min). In total, $10 \mu \mathrm{l}$ of each virus-specific antiserum were pipetted onto 2 wells (PBS was pipetted on negative control wells). On the slides coated with cells infected with the positive control viruses, 2 wells were overlaid with the homologous antiserum and 2 wells were covered with a heterologous antiserum. The antisera used were obtained from 2 different sources: (1) commercial kits (monoclonal antibodies): BIO-FLUO IHN; BIO-FLUO VHS; BIO-FLUO IPN (Bio-X), and (2) polyclonal anti-perch rhabdovirus DFVF-26 kindly provided by the European Union Reference Laboratory for Fish Diseases (DTU, Copenhagen). The slides were incubated ( $2 \mathrm{~h}, \mathrm{RT})$ in a humid chamber before washing (10 $\mathrm{min}, \mathrm{PBS}$ ) and drying (15 min, RT). A total of $10 \mu \mathrm{l}$ of the secondary, fluorescein isothiocyanate-conjugated anti-mouse anti- serum (BIO-FLUO kits) or a swine anti-rabbit (Dako) antiserum for the Danish antiserum, respectively, were added. Slides were incubated in a humid chamber (1 h, RT), washed (10 min, distilled water), covered with mounting medium (BIOFLUO kits) and stored (humid chamber, $4^{\circ} \mathrm{C}$ ) for a maximum of $2 \mathrm{~h}$ until reading. The results were interpreted as positive if intracellular fluorescence was at least as intense as the positive control. Viruses testing positive with the anti-perch rhabdovirus antiserum were sent to the French Agency for Food, Environmental and Occupational Health \& Safety (Plouzané, France) for further investigation.

\section{Further identification of isolated virus by IFAT}

Isolated virus that tested positive with the antiperch rhabdovirus antibodies was further characterized as described below. Rabbit antisera against 3 perch rhabdovirus reference strains were used to test the antigenic properties of the Swiss perch isolate. The antibodies were directed against isolate DK5533 originating from Denmark in 1989 and 2 strains isolated in France in 1980 and 2005, and identified as perch rhabdovirus (PRV) (first original isolate) and R6146 (recently positioned in the STRV species; Table 1) (Dorson et al. 1984, Jørgensen et al. 1993, Betts et al. 2003, Talbi et al. 2011, ICTV 2013, Stone et al. 2013). Briefly, cultures of RTG-2 (rainbow trout gonad) and CHSE-214 (Chinook salmon embryo) cell lines in 96-well plates were infected with the Swiss isolate. PRV, DK5533 and 2 other PRV strains detected in France (9574.01 and N4925; Table 1) were used as positive controls (Talbi et al. 2011). At $48 \mathrm{~h}$ post-infection, the cell cultures were rinsed twice with PBS and fixed in $80 \%$ cold acetone. Virus-specific rabbit antisera were applied as the primary antibody and the
Table 1. Viral isolates used in this study. PRV: perch rhabdovirus; na: not applicable (strain R6146 repositioned to the species Sea trout rhabdovirus)

\begin{tabular}{|c|c|c|c|c|c|c|}
\hline \multirow[t]{2}{*}{ Strain } & \multirow[t]{2}{*}{ Origin } & \multirow{2}{*}{$\begin{array}{l}\text { Year of } \\
\text { isolation }\end{array}$} & \multirow{2}{*}{$\begin{array}{c}\text { Host } \\
\text { species }\end{array}$} & \multirow[t]{2}{*}{ Genotype } & \multicolumn{2}{|c|}{ Accession no. } \\
\hline & & & & & G gene $^{\mathrm{a}}$ & $\mathrm{Ng}_{\text {gene }}{ }^{\mathrm{a}}$ \\
\hline PRV & France & 1980 & Perch & A & JX679246 & JX679246 \\
\hline 27V10 & Italy & 2010 & Perch & A & JF502605 & JF502619 \\
\hline M7173-1 & France & 2002 & Perch & A & JF502610 & JF502626 \\
\hline 9574.01 & France & 2009 & Perch & B & JF502613 & JF502617 \\
\hline DK5533 & Denmark & 1993 & Pike & $\mathrm{C}$ & JF502603 & JF502627 \\
\hline N4925 & France & 2003 & Perch & $\mathrm{D}$ & JF502604 & JF602629 \\
\hline R6146 & France & 2005 & Perch & na & JF502608 & JF502632 \\
\hline
\end{tabular}


plates were incubated for $1 \mathrm{~h}$ at $37^{\circ} \mathrm{C}$. After washing 3 times with PBS, a FITC-conjugated antirabbit Ig (Sigma) was added as a secondary antibody and incubated for $1 \mathrm{~h}$ at $37^{\circ} \mathrm{C}$. The processed cultures were examined using an epifluorescence microscope.

\section{RNA extraction, RT-PCR and sequencing}

RNA was extracted from $150 \mu$ of cell culture supernatant using the Nucleospin RNA virus kit (Macherey-Nagel). The complete glycoprotein gene (1560 bp) was amplified using 2 primer pairs targeting overlapping sequences. Primers used were oPVP116 and oPVP118 (Talbi et al. 2011) targeting a sequence of $1400 \mathrm{bp}$ and oPVP126 (Talbi et al. 2011) and oPVP124 (5'-CAC ATC CCT TGA TGG AAT AC-3') targeting a partial sequence of $797 \mathrm{bp}$. For the nucleoprotein, only a partial sequence (651 bp) was amplified with the primers oPVP141 and oPVP143 (Talbi et al. 2011). One-step RT-PCR reactions were performed with the SuperScript III One-Step RT-PCR System with Platinum Taq High fidelity (Invitrogen) using the following mix: approximately $1 \mu \mathrm{g}$ of RNA was added to $20 \mu \mathrm{M}$ of each primer, $1 \mu \mathrm{l}$ of Taq, $25 \mu \mathrm{l}$ of reaction mix and water in a final volume of $50 \mu \mathrm{l}$. The G-gene RTPCRs were conducted in a Mastercycler (Eppendorf) with an initial step of $55^{\circ} \mathrm{C}(30 \mathrm{~min})$ followed by one step at $94^{\circ} \mathrm{C}(2 \mathrm{~min})$ then 35 cycles of $94^{\circ} \mathrm{C}$ $(30 \mathrm{~s}), 45^{\circ} \mathrm{C}(30 \mathrm{~s})$ and $68^{\circ} \mathrm{C}(60 \mathrm{~s})$. The N-gene RTPCR was conducted in a Mastercycler with an initial step of $55^{\circ} \mathrm{C}$ (30 min) followed by one step at $94^{\circ} \mathrm{C}(2 \mathrm{~min})$ then $35 \mathrm{cycles}$ of $94^{\circ} \mathrm{C}(30 \mathrm{~s}), 48^{\circ} \mathrm{C}$ $(30 \mathrm{~s})$ and $72^{\circ} \mathrm{C}(30 \mathrm{~s})$; and a final extension at $68^{\circ} \mathrm{C}$ (5 min). After agarose gel electrophoresis, which confirmed the correct sizes of the products, all PCR products were purified with a NucleoSpin gel and PCR clean-up kit (Macherey-Nagel) and cloned using the TOPO TA cloning kit (Invitrogen). For each PCR product, 3 clones were selected and sequenced in both directions, and all nucleotide differences were checked visually using VectorNTI v.11.5 software.

\section{Phylogenetic reconstruction and sequence comparisons}

All consensus sequences were assembled using VectorNTI v.11.5. Alignments were performed with the 'Muscle' program in SeaView v.4 (Gouy et al.
2010). Gaps were removed using 'Gblocks' (Castresana 2000) carried out on the 'phylogeny.fr' platform (Dereeper et al. 2008). Phylogenetic reconstructions were realized using both neighbor-joining $(\mathrm{NJ})$ and maximum likelihood (ML) in SeaView v.4. ML was performed using 'PhyML' (Guindon \& Gascuel 2003, Guindon et al. 2005) with an evolutionary model selected via Akaike's information criterion with 'jModelTest 2' (Darriba et al. 2012). For the partial N gene (data set of 15 nucleotide sequences) and complete $\mathrm{G}$ gene (data set of 22 nucleotide sequences), a general time reversible model (GTR) with a gamma distribution ( $\Gamma=0.36$ and 0.39 respectively) was chosen. NJ was performed using Jukes and Cantor parameters. Both methods were validated with 1000 bootstrap replicates. The glycoprotein sequence of the Swiss isolate was compared using the software Geneious v.7.0 (Kearse et al. 2012) to those of strains PRV, 9574.01, DK5533, 27V10, M7173-1 and N4925 (Table 1).

\section{RESULTS}

\section{Post mortem examination and virus isolation}

The only visible macroscopic sign of disease observed in fish was abnormal swimming behavior expressed as bouts of spiraling and swimming to the surface followed by sinking to the bottom and lethargy. Further, cumulative mortality of about $13 \%$ was observed. Parasitological investigation of individuals from Submission 1 revealed a light to moderate infection of the skin and gills by Ichthyobodo necator. Bacteriological analysis showed a low number of various bacterial colonies (not identified) in only one fish while all other fish were negative. Histological examination revealed no tissue alterations, and in particular, no alterations in the brain were seen. The presence of a virus was detected by virological examination. Viral growth was seen exclusively in BF-2 cell cultures. Immunofluorescence tests were negative using antibodies specific for VHSV, IHNV and infectious pancreatic necrosis virus (IPNV). However a positive result was obtained with the Danish anti-perch rhabdovirus antibody (DFVF-26).

From Submissions 2 to 4, CPE was recorded in BF2 cells inoculated with brain material from fish showing abnormal swimming behavior. All other samples were negative. Again, the grown virus could be identified as perch rhabdovirus using the Danish antiperch rhabdovirus antibody (Table 2). 
Table 2. Clinical signs and virological observations. Presence of cytopathic effect (CPE) in bluegill fry (BF-2) cell cultures, organs tested and presence of disease signs are reported for each tank $(1,2)$ and submission (Sub. 1 to 4 )

\begin{tabular}{|ccclc|}
\hline $\begin{array}{c}\text { Tank } \\
\text { no. }\end{array}$ & $\begin{array}{c}\text { Sub. } \\
\text { Disease } \\
\text { signs }\end{array}$ & Organ sampled & CPE \\
\hline 1 & 1 & Yes & $\begin{array}{l}\text { Pooled brain, heart, spleen, } \\
\text { kidney, caeca pylorica }\end{array}$ & Yes \\
& 2 & Yes & $\begin{array}{l}\text { Brain } \\
\text { Pooled heart, spleen, } \\
\text { kidney, caeca pylorica }\end{array}$ & $\begin{array}{c}\text { Yes } \\
\text { No } \\
\end{array}$ \\
& & No & $\begin{array}{l}\text { Brain } \\
\text { Pooled heart, spleen, } \\
\text { kidney, caeca pylorica } \\
\text { Brain } \\
\text { Pooled heart, spleen, }\end{array}$ & No \\
& 4 & No & No \\
& & & & \\
\hline
\end{tabular}

\section{Phylogenetic analysis}

Phylogenetic reconstructions produced the same topologies for each gene using either NJ or ML (Fig. 1). The new Switzerland perch strain clustered within the species Perch rhabdovirus. Inside this species, 4 genotypes (A-D) were clearly distinguished and strongly supported (NJ and ML bootstrap support $>70$ ), as described previously (Talbi et al. 2011). The Switzerland perch isolate belongs to genotype C with the viral strain identified as DK5533. These 2 viral strains were closely related with $98.1 \%$ and $99.5 \%$ nucleotide identity for the G gene and the $\mathrm{N}$ gene, respectively.

\section{Serological characterization}

RTG-2 and CHSE-214 cell cultures infected with the reference strains PRV (genotype A) and DK5533

Table 3. Immunofluorescence profile obtained with virus-infected CHSE-214 and RTG-2 cells, the Swiss isolate of perch rhabdovirus (in bold), using antisera against reference perch virus strains. Positive reactions are indicated by a ' + ', negative ones by a 0 . Genotypes of the perch rhabdovirus strains used are specified (in parentheses). Two serogroups (I, II) are proposed based on the serological profiles obtained. Isolate R6146 is a strain representative of the species Sea trout rhabdovirus (STRV)

\begin{tabular}{|lccccc|}
\hline $\begin{array}{l}\text { Isolate } \\
\text { (genotype) }\end{array}$ & Host & \multicolumn{5}{c|}{$\begin{array}{l}\text { Rabbit antiserum against } \\
\text { PRV }\end{array}$} & $\begin{array}{c}\text { DK5533 } \\
\text { (A) }\end{array}$ & $\begin{array}{c}\text { R6146 } \\
\text { (C) }\end{array}$ & $\begin{array}{c}\text { Proposed } \\
\text { serogroup }\end{array}$ \\
\hline PRV (A) & Perch & + & + & 0 & I \\
9574.01 (B) & Perch & + & + & 0 & I \\
DK5533 (C) & Pike & 0 & + & 0 & II \\
N4925 (D) & Perch & + & + & 0 & I \\
Swiss isolate (C) & Perch & + & + & $\mathbf{0}$ & I \\
\hline
\end{tabular}

(genotype C) were clearly positive in IFAT using homologous antisera (Table 3), and isolates 9574.01 (genotype B) and N4925 (genotype D) were positive using a heterologous antiserum against PRV. Strains PRV, 9574.01 and N4925 were also positive using antisera specific to DK5533. Surprisingly, the serological profile of the Swiss perch rhabdovirus isolate was similar to those of strains PRV, 9574.01 and N4925, despite its close genetic proximity to strain DK5533. Cells infected with all these viral strains were negative using an antiserum specific to the STRV strain R6146 isolated from perch. Based on these serological relationships, 2 serological groups can be hypothesized: the first contains PRV, 9574.01, N4925 and the Swiss isolate (serogroup I, SI), the second contains strain DK5533 (serogroup II, SII).

\section{Comparison of the glycoprotein amino-acid sequences of the 2 serogroups}

The Swiss isolate G gene had 99.2, 95.6 and 95.8\% amino acid identity with that of strains DK5533, PRV and 9574.01, respectively. The alignment of the deduced glycoprotein sequences of these 4 strains allowed the identification of 12 positions for which amino acids were common between the Swiss (SI) and DK5533 (SII) strains but distinct from the PRV and 9574.01 isolates (SI; Table 4). Only one substitution of a proline by a serine in position 147 was observed when comparing the DK5533 (SII) strain with the 3 other perch rhabdovirus isolates from serogroup I. Perch rhabodovirus strains 27V10 and M7173-1 (genotype A and serogroup I, data not shown), isolated in Italy in 2010 and in France in 2002, respectively, showed a pattern similar to isolates PRV and 9574.01 for the 13 amino acid positions studied. Amino acids in positions 375, 432,486 and 490 of the G protein were similar for strains N4925 (genotype D), DK5533 and the Swiss isolate.

\section{DISCUSSION}

A perch rhabdovirus was detected for the first time from perch in Switzerland. The virus was detected in perch from a commercial fish farm. Fish showed abnormal spiraling swimming behavior interspersed with phases of lethargy; signs that are consistent with those described for perch infected by 

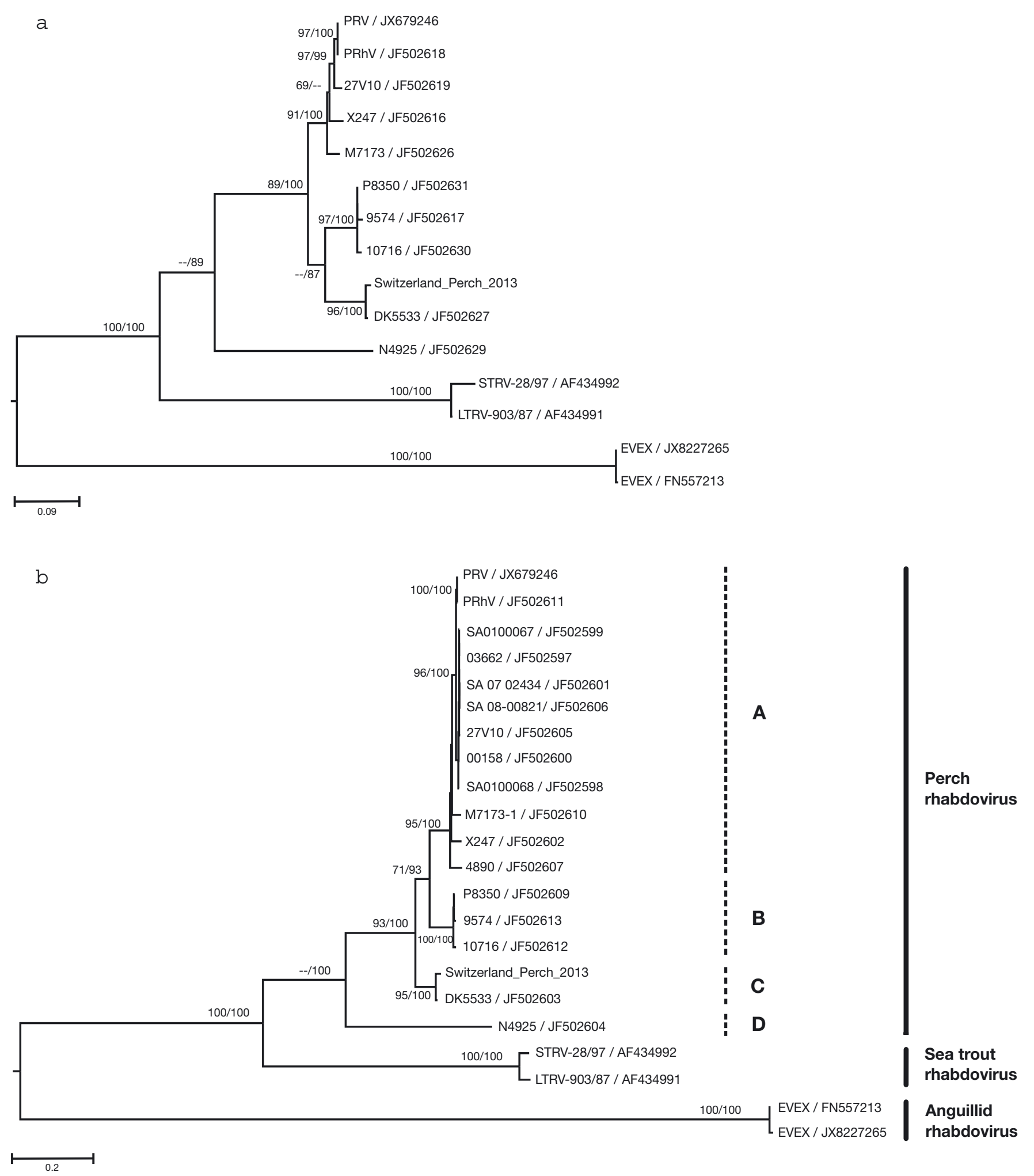

Fig. 1. Positioning of the Swiss perch rhabdovirus isolate in phylogenetic trees computed from the (a) partial $\mathrm{N}$ gene and (b) complete G gene by maximum likelihood (ML) and neighbor-joining (NJ). Bootstrap values (ML/NJ) are indicated at the nodes reflecting clade support (values below 70 are indicated by dashes). Sequence names include isolate code and Genbank accession numbers except for the new virus from Switzerland which is assigned as Switzerland_Perch_2013. Species names and the 4 genotypes (A-D) are indicated. Scale bars: nucleotide substitutions site ${ }^{-1}$ 
Table 4. Amino acid differences observed for the glycoprotein among the perch rhabdovirus strains representative of the 2 serogroups identified. The row in bold corresponds to the only amino acid (aa) for which DK5533 differs from the Swiss isolate. Light gray shading: positions for which identical aa were observed for strains PRV, 9574.01, 27V10, MM7173-1, N4925 and the Swiss isolate; dark grey shading: aa common to strains DK5533, N4925 and the Swiss isolate. The Roman numeral in parentheses corresponds to serogroups I and II defined in Table 3

\begin{tabular}{|c|c|c|c|c|}
\hline \multirow{2}{*}{ Position } & \multirow[b]{2}{*}{$\begin{array}{c}\text { PRV 9574.01 } \\
27 \mathrm{~V} 10^{\mathrm{a}} \\
\mathrm{M}^{2} 173-1^{\mathrm{a}}(\mathrm{I})\end{array}$} & \multicolumn{2}{|c|}{ Amino acid - } & \multirow[b]{2}{*}{$\begin{array}{l}\mathrm{N} 4925 \\
\text { (I) }\end{array}$} \\
\hline & & $\begin{array}{l}\text { DK5533 } \\
\text { (II) }\end{array}$ & $\begin{array}{l}\text { Swiss isolate } \\
\text { (I) }\end{array}$ & \\
\hline 33 & $\mathrm{~T}$ & $\mathrm{~A}$ & A & $\mathrm{T}$ \\
\hline 37 & $\mathrm{D}$ & $\mathrm{S}$ & $\mathrm{S}$ & $\mathrm{D}$ \\
\hline 58 & $\mathrm{E}$ & $\mathrm{K}$ & $\mathrm{K}$ & $E$ \\
\hline 147 & $\mathbf{S}$ & $\mathbf{P}$ & $\mathbf{S}$ & $\mathbf{S}$ \\
\hline 248 & $\mathrm{~S}$ & $\mathrm{~A}$ & A & $\mathrm{S}$ \\
\hline 270 & K & $\mathrm{E}$ & $\mathrm{E}$ & K \\
\hline 277 & $E$ & $\mathrm{G}$ & $\mathrm{G}$ & $\mathrm{E}$ \\
\hline 371 & $\mathrm{~V}$ & I & I & $\mathrm{V}$ \\
\hline 375 & $\mathrm{~K}$ & $\mathrm{R}$ & $\mathrm{R}$ & $\mathrm{R}$ \\
\hline 431 & I & V & V & I \\
\hline 432 & $\mathrm{P}$ & Q & Q & Q \\
\hline 486 & I & V & V & V \\
\hline 490 & $\mathrm{~V}$ & I & I & I \\
\hline
\end{tabular}

${ }^{a}$ From amino acid sequences published by Talbi et al. (2011) and Stone et al. (2013)

perch rhabdovirus by other authors (Betts et al. 2003). As in other descriptions (Dannevig et al. 2001) no macroscopic nor histologic tissue alterations were detected. Interestingly, the virus could be only isolated from fish showing spiral swimming, while all tests performed on fish with normal swimming behavior were negative, regardless of whether the fish were from the same tank and year class or from other tanks connected to the same recirculation system. Further, only inoculation of cell lines with brain material resulted in a CPE while no virus could be detected using other tissues (pools of heart, spleen and kidney). Mortalities occurred on several occasions about 3 wk after stocking imported fish in the recirculation system, where fish from previous stockings of different origins were present. New fish were received from a stock that tested negative for PRV. However, the documented results on the certificate were based on virological examination of organs other than brain, thus excluding even the possibility of detecting virus located in this specific tissue. Several studies reported viral persistence associated with central nervous system (CNS) tissue during a chronic phase of infection with VHSV while virus was mostly cleared from other tissues (Neukirch
1986, Oidtmann et al. 2011, Lovy et al. 2012) and neurotropic forms of IHNV have also been described (LaPatra et al. 1995). It may therefore be important in the future to include brain tissue samples for detection of perch rhabdovirus. Alternatively, the virus could have been present as a sub-clinical infection in the Swiss facility and subsequently transmitted to newly stocked fish (i.e. post-stocking), resulting in these naïve fish becoming diseased.

Phylogenetic analysis based on the partial RNA polymerase and entire glycoprotein gene sequences confirmed the classification of this isolate as a perch rhabdovirus from genogroup $\mathrm{C}$ and revealed that it was closely related, with more than $98 \%$ identities of nucleotide and amino acid sequences, to the DK5533 strain isolated from pike in Denmark in 1989 (Jørgensen et al. 1993, Talbi et al. 2011, Gadd et al. 2013). The high level of identity between strains isolated in 2 distant regions can be explained by movement of infected fish between the 2 places or, alternatively, a common origin for these 2 viruses, likely through the introduction of infected fish in both places from a common source before 1989. RNA viruses are often assumed to evolve quickly with a mutation rate ranging between $10^{-2}$ and $10^{-5}$ nucleotide substitutions site $^{-1} \mathrm{yr}^{-1}$ (Jenkins et al. 2002, Duffy et al. 2008, Sanjuan 2012). Based on the comparison of glycoprotein gene sequences, the rates observed for strain DK5533 (1989) and our Swiss isolate (2013) are within the range for RNA viruses, around $10^{-5}$ nucleotide substitutions site $\mathrm{yr}^{-1}$. This substitution rate suggests that the movement of infected fish between 2 places is more likely than a common origin of these 2 viruses. Traceability of fish movements between farms is an important element that could help to link the phylogenetic data with field observations.

The $\mathrm{G}$ protein of rhabdoviruses is a trimeric transmembrane protein extending outwards containing a range of antigens involved in virus neutralization and serotype discrimination (Coll 1995). It plays an essential role in both the early and the final phases of infection by mediating attachment to host cell receptors and internalization of the virus, and also particlebudding during exit. Competitive antibody-binding studies and analyses of neutralization-escape mutants have allowed the identification and location of major antigenic sites in the G proteins of several rhabdoviruses (Walker \& Kongsuwan 1999). The absence of serological cross-reactivity between the isolate R6146 and those representatives from genogroups A (PRV) and B (9574.01) has been reported and can be explained by the low sequence identi- 
ties (ranging from 32 to $34.9 \%$ ) observed between these 2 groups for the entire G genes (Talbi et al. 2011). Strain R6146, initially placed in the genogroup E of perch rhabdoviruses, was recently reassigned to the STRV species (Dannevig et al. 2001, Talbi et al. 2011, ICTV 2013, Gadd et al. 2013). Our results show that 2 serogroups can be hypothesized within the species Perch rhabdovirus using 2 polyclonal antisera. The first group could be composed of strains PRV, 27V10, M7173-1 (genotype A) and 9574.01 (genotype B) which have an identical pattern for all 13 amino acid positions of the $\mathrm{G}$ protein identified as possibly involved in the antigenicity of the virus, but also of strain N4925 (genotype D) and our Swiss isolate (genotype C). The second group could contain strain DK5533 (genotype C) isolated from pike. Interestingly, 2 strains (DK5533 and our Swiss isolate) from a same genetic cluster appear to belong to different serogroups. Absence or little correlation between serotypes and genotypes has been described for VHSV and IHNV (Johansson et al. 2009). Further work on new isolates will be needed to clarify serological relationships within the species Perch rhabdovirus.

Topological analyses using the Phobius server of the G protein of the Swiss isolate predict an N-terminal signal peptide (aa 1-19) followed by an ectodomain (aa 20-469), a transmembrane domain (aa 470-492), and a C-terminal cytoplasmic tail (aa 493-506). The proline in position 147 of the $\mathrm{G}$ protein in strain DK5533 is the only amino acid that differs from the Swiss isolate which, like all the other strains of the serogroup I, has a serine in this position.

Proline is a unique amino acid with a particular 5membered nitrogen-containing ring and is consequently unable to occupy many of the main chain conformations easily adopted by all other amino acids (Betts \& Russel 2003). Proline is involved in the folding of several surface proteins such as hemagglutinin in influenza virus (Simpson et Lamb 1991), glycoprotein in measles virus (Plemper et Compans 2003) or Env protein in Moloney murine leukemia virus (Taylor et Sanders 1999), particularly through its role in sharp changes in the direction of the helix axis (kinks). Our observation suggests that the aa in position 147 of the $G$ protein could have a role in serological discrimination of perch rhabdovirus isolates, probably through a conformational change. Interestingly, the N4925 strain representing genotype D showed a hybrid amino acid profile with 9 of 13 aa in the same positions as strains PRV, 9574.1, 27V10 and M7173-1 and 4 of 13 aa with the same locations as strain DK 5533 and our Swiss isolate.
In conclusion, this study reports the first case of disease caused by infection with perch rhabdovirus in a Swiss farm and emphasizes the difficulty in effectively diagnosing sub-clinical infections. The high identity of the Swiss perch rhabdovirus isolate with a strain described in Denmark in 1989 strongly suggests that movements of fish contributed to the spread of pathogens. As the nervous system may be involved in viral persistence, fish health screening assays should consider including brain tissue, particularly for perch where knowledge of infectious diseases is scant. Further work on new isolates will also be needed to clarify serological relationships within the species Perch rhabdovirus.

Acknowledgements. We are grateful to the following colleagues for kindly supplying virus or antisera: N. J. Olesen (DTU, Denmark), G. Bovo (IZSVie, Italy), P. Boudinot and P. De Kinkelin (INRA-VIM, France), P. Daniel and M. Chague (Laboratoire des Pyrénées et des Landes, France) and F. Pozet (Laboratoire Départemental d'Analyses du Jura, France)

\section{LITERATURE CITED}

Ahne W, Bjorklund HV, Essbauer S, Fijan N, Kurath G, Winton JR (2002) Spring viremia of carp (SVC). Dis Aquat Org 52:261-272

Al-Hussinee L, Lord S, Stevenson RMW, Casey RN and others (2011) Immunohistochemistry and pathology of multiple Great Lakes fish from mortality events associated with viral hemorrhagic septicemia virus type IVb. Dis Aquat Org 93:117-127

Anonymous (1995) Ordinance on epizootic diseases: SR 916.401. The Swiss Federal Council, Bern

Anonymous (2001) Commission decision of 22 February 2001 (2001/183/CE) laying down the sampling plans and diagnostic methods for the detection and confirmation of certain fish diseases and repealing Decision 95/535/EEC. Off J Eur Comm L 67:65-76 (accessed 3 Dec 2014)

Anonymous (2006) Council Directive 2006/88/EC of 24 October 2006 on animal health requirements for aquaculture animals and products thereof, and on the prevention and control of certain diseases in aquatic animals. Off J Eur Union L 328:14-56 (accessed 3 Dec 2014)

Betts AM, Stone DM, Way K, Torhy C, Chilmonczyk S, Benmansour A, de Kinkelin P (2003) Emerging vesiculo-type virus infections of freshwater fishes in Europe. Dis Aquat Org 57:201-212

Betts MJ, Russell RB (2003) Amino acid properties and consequences of substitutions. In: Barnes MR, Gray IC (eds) Bioinformatics for geneticists. John Wiley \& Sons, Chichester, p 289-316

Castresana J (2000) Selection of conserved blocks from multiple alignments for their use in phylogenetic analysis. Mol Biol Evol 17:540-552

Coll JM (1995) The glycoprotein G of rhabdoviruses. Arch Virol 140:827-851

Dannevig BH, Olesen NJ, Jentoft S, Kvellestad A, Taksdal T, Hastein $\mathrm{T}$ (2001) The first isolation of a rhabdovirus from 
perch (Perca fluviatilis) in Norway. Bull Eur Assoc Fish Pathol 21:186-194

Darriba D, Taboada GL, Doallo R, Posada D (2012) jModelTest 2: more models, new heuristics and parallel computing. Nat Methods 9:772

Dereeper A, Guignon V, Blanc G, Audic S and others (2008) Phylogeny.fr: robust phylogenetic analysis for the nonspecialist. Nucleic Acids Res 36(Suppl 2):W465-W469

> Dorson M, Torchy C, Chilmonczyck S, De Kinkekin P, Michel C (1984) A rhabdovirus pathogenic for perch, Perca fluviatilis L.: isolation and preliminary study. J Fish Dis 7:241-245

Duffy S, Shackelton LA, Holmes EC (2008) Rates of evolutionary change in viruses: patterns and determinants. Nat Rev Genet 9:267-276

Faisal M, Shavalier M, Kim RK, Millard EV and others (2012) Spread of the emerging viral hemorrhagic septicemia virus strain, genotype IVb, in Michigan, USA. Viruses 4: $734-760$

> Gadd T, Viljamaa-Dirks S, Holopainen R, Koski P, JakavaViljanen M (2013) Characterization of perch rhabdovirus (PRV) in farmed grayling Thymallus thymallus. Dis Aquat Org 106:117-127

Galinier R, van Beurden S, Amilhat E, Castric J and others (2012) Complete genomic sequence and taxonomic position of eel virus European X (EVEX), a rhabdovirus of European eel. Virus Res 166:1-12

> Gouy M, Guindon S, Gascuel O (2010) SeaView version 4: a multiplatform graphical user interface for sequence alignment and phylogenetic tree building. Mol Biol Evol 27:221-224

Guindon S, Gascuel O (2003) A simple, fast, and accurate algorithm to estimate large phylogenies by maximum likelihood. Syst Biol 52:696-704

Guindon S, Lethiec F, Duroux P, Gascuel O (2005) PHYML Online-a web server for fast maximum likelihoodbased phylogenetic inference. Nucleic Acids Res 33 (Suppl 2):W557-W559

Healy DM, Banyard AC, Fooks AR (2013) Rhabdoviruses. eLS, doi:10.1002/9780470015902.a0001085.pub3

Hoffmann B, Schütze H, Mettenleiter TC (2002) Determination of the complete genomic sequence and analysis of the gene products of the virus of Spring Viremia of Carp, a fish rhabdovirus. Virus Res 84:89-100

ICTV (International Committee on Taxonomy of Viruses) (2013) Virus taxonomy: 2013 release. www.ictvonline. org/virusTaxonomy.asp?taxnode_id=20130492 (accessed 3 Dec 2014)

Jenkins GM, Rambaut A, Pybus OG, Holmes EC (2002) Rates of molecular evolution in RNA viruses: a quantitative phylogenetic analysis. J Mol Evol 54:156-165

Johansson T, Einer-Jensen K, Batts W, Ahrens P and others (2009) Genetic and serological typing of European infectious haematopoietic necrosis virus (IHNV) isolates. Dis Aquat Org 86:213-221

Jørgensen PEV, Olesen NJ, Ahne W, Wahli T, Meier W

Editorial responsibility: Mark Crane,

Geelong, Victoria, Australia
(1993) Isolation of a previously undescribed rhabdovirus from pike Esox lucius. Dis Aquat Org 16:171-179

Kearse M, Moir R, Wilson A, Stones-Havas S and others (2012) Geneious Basic: an integrated and extendable desktop software platform for the organization and analysis of sequence data. Bioinformatics 28:1647-1649

> LaPatra SE, Lauda KA, Jones GR, Walker SC, Shewmaker BS, Morton AW (1995) Characterization of IHNV isolates associated with neurotropism. Vet Res 26:433-437

> Lovy J, Lewis NL, Hershberger PK, Bennett W, Meyers TR, Garver KA (2012) Viral tropism and pathology associated with viral hemorrhagic septicemia in larval and juvenile Pacific herring. Vet Microbiol 161:66-76

Neukirch M (1986) Demonstration of persistent viral haemorrhagic septicemia (VHS) virus in rainbow trout after experimental waterborne infection. J Vet Med Ser B 33: 471-476

> Oidtmann B, Joiner C, Stone D, Dodge M, Reese RA, Dixon $P$ (2011) Viral load of various tissues of rainbow trout challenged with viral haemorrhagic septicaemia virus at various stages of disease. Dis Aquat Org 93:93-104

OIE (World Organisation for Animal Health) (2014) Manual of diagnostic tests for aquatic animals. OIE, Paris. www. oie.int/en/international-standard-setting/aquatic-manual/ access-online/ (accessed 3 Dec 2014)

Plemper RK, Compans RW (2003) Mutations in the putative $\mathrm{HR}-\mathrm{C}$ region of the measles virus $\mathrm{F}_{2}$ glycoprotein modulate syncytium formation. J Virol 77:4181-4190

Pozet F, Morand M (2005) Pathologie de la perche. Aquafilia 9:23-27

Sanjuán R (2012) From molecular genetics to phylodynamics: evolutionary relevance of mutation rates across viruses. PLoS Pathog 8:e1002685

Simpson DA, Lamb RA (1991) Influenza virus ts61S hemagglutinin is significantly defective in polypeptide folding and intracellular transport at the permissive temperature. Virology 185:477-483

Stone DM, Kerr RC, Hughes M, Radford AD, Darby AC (2013) Characterization of the genomes of four putative vesiculoviruses: tench rhabdovirus, grass carp rhabdovirus, perch rhabdovirus and eel rhabdovirus European X. Arch Virol 158:2371-2377

> Talbi C, Cabon J, Baud M, Bourjaily M, de Boisseson C, Castric J, Bigarre L (2011) Genetic diversity of perch rhabdoviruses isolates based on the nucleoprotein and glycoprotein genes. Arch Virol 156:2133-2144

Taylor GM, Sanders DA (1999) The role of the membranespanning domain sequence in glycoprotein-mediated membrane fusion. Mol Biol Cell 10:2803-2815

> Walker PJ, Kongsuwan K (1999) Deduced structural model for animal rhabdovirus glycoproteins. J Gen Virol 80: 1211-1220

- Way K, Bark SJ, Longshaw CB, Denham KL and others (2003) Isolation of a rhabdovirus during outbreaks of disease in cyprinid fish species at fishery sites in England. Dis Aquat Org 57:43-50

Submitted: December 22, 2014; Accepted: July 17, 2015

Proofs received from author(s): September 20, 2015 